\title{
INTRODUCTION TO SYMPOSIUM: THE POPE'S ENCYCLICAL AND CLIMATE CHANGE POLICY
}

\author{
Tom Ginsburg*
}

As the world prepares for the opening of the Paris Climate Change conference, AJIL Unbound is pleased to offer a set of reflections on Laudato Si, Pope Francis' Encyclical Letter On Care for Our Common Home. ${ }^{1}$ Released in May 2015, it has generated much commentary and debate, both because of its contents and its source. Pope Francis is calling on the world to rethink the relationships among the economy, the environment and morality, and to develop a spiritually grounded ethic that will inform institutions.

We have a wonderful and diverse set of authors to engage with the Encyclical. We begin with a philosophical perspective from Dale Jamieson, who characterizes the work as one of moral theology, rather than a political intervention. ${ }^{2}$ He situates the Pope's views within contemporary philosophy, and explains that what the Pope is hoping to do is to stimulate an ethical conversation on environment and development, rather than make a narrowly political intervention.

Dan Bodansky takes a more practical view. ${ }^{3}$ Any impact of the Encyclical, he argues, will likely have more to do with the person of the author than the novelty of the arguments, which draw on themes familiar from the environmental movement. And while agreeing that climate change is a moral issue, Bodansky warns that it is an economic and technological one too. Economic and technological tools may help us to address the problem, and should not be rejected out of hand.

Dinah Shelton points out that other religious traditions have environmental ethics as well, implying that there is potential for a grand coalition of moral thinkers on the question. ${ }^{4}$ Complementing this demonstration of the compatibility of the Pope's ideas with those of other faiths, Ileana Porras then situates the Encyclical within the tradition of Catholic social thought. ${ }^{5}$ She shows how it is at the same time a radical document and one that fits squarely in its own religious tradition. Her perspective provides helpful framing for non-Catholic readers to understand the goals and idiom of the document and how it interacts with law.

* Deputy Dean, Leo Spitz Professor of International Law, Ludwig and Hilde Wolf Research Scholar, and Professor of Political Science, University of Chicago.

Originally published online 25 November 2015.

1 Pope Francis, Encyclical LetTer Laudato Si’ of THe Holy Father Francis on Care for our Common Home, para. 106 (2015).

2 Dale Jamieson, Theology and Politics in Laudato Si', 109 AJIL UnBound 122 (2015).

${ }^{3}$ Daniel Bodansky, Should We Care What The Pope Says About Climate Change?, 109 AJIL Unbound 127 (2015).

${ }^{4}$ Dinah Shelton, Dominion and Stewardship, 109 AJIL Unbound 132 (2015).

5 Ileana M. Porras, Laudato Si', Pope Francis' Call to Ecological Conversion, Responding to the Cry of the Earth and the Poor-Towards an Integral Ecology, 109 AJIL UnBOUND 136 (2015) 
Lavanya Rajamani examines the Encyclical from the perspective of international environmental law, specifically the principle of Common but Differentiated Responsibilities. ${ }^{6}$ As she points out, the Papal Encyclical endorses two of the key underpinnings of the principle, namely that all states must contribute to resolving environmental problems, and that obligations are to be assigned based on capacity. Finally, Lincoln Davies examines the Encyclical from the perspective of U.S. energy law, which he characterizes as profoundly amoral. ${ }^{7}$ Because law is biased toward endless generation and consumption, and because consumers cannot see the full impact of their choices, our legal regime contributes in a direct way toward the problems identified in the Encyclical. In this way, we move from the philosophical to the legal and institutional, suggesting directions for concrete reforms to address the problems the Pope so profoundly identifies.

${ }^{6}$ Lavanya Rajamani, The Papal Encyclical \& the Role of Common but Differentiated Responsibilites in the International Climate Change Negotiations, 109 AJIL Unbound 142 (2015).

${ }^{7}$ Lincoln L. Davies, Energy, Consumption, and the Amorality of Energy Law, 109 AJIL UnBound 147 (2015). 